\title{
Honeybees diversity, pollination, entrepreneurship and beekeeping scenario in NEH region of India
}

\author{
SM Haldhar, CN Nidhi, KI Singh \& AS Devi
}

Journal of Agriculture and Ecology

Volume-12 (December, 2021) ISSN: $2456-9410$

ISSN: 2456-9410

\section{Volume: 12}

Journal of Agriculture and Ecology (2021) 12: 27-43 http://doi.org/10.53911/JAE.2021.12202

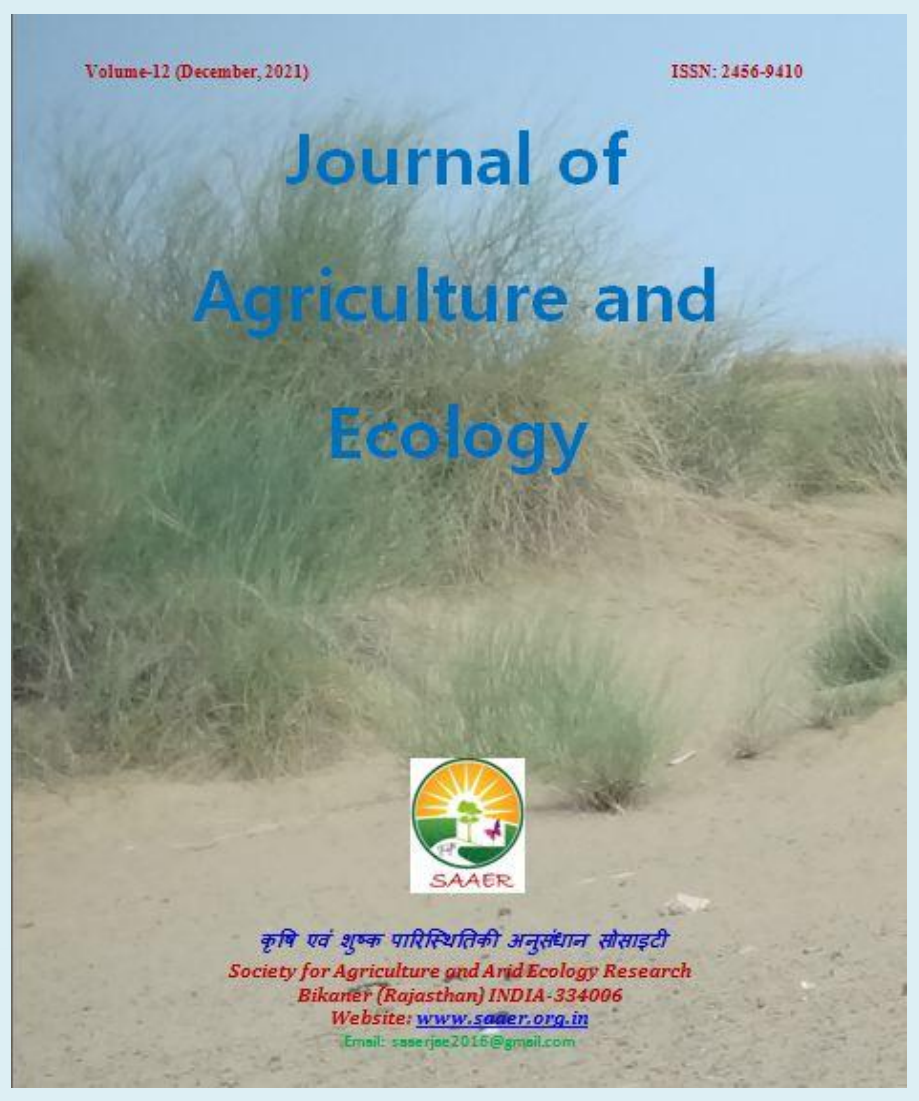




\section{Review Article}

Open Access

\section{Honeybees diversity, pollination, entrepreneurship and beekeeping scenario in NEH region of India \\ SM Haldhar $\bigvee$ CN Nidhi, KI Singh \& AS Devi \\ Department of Entomology, College of Agriculture, CAU, Imphal, Manipur-795004 \\ D Corresponding author: DK Samadia,E-mail: haldhar80@gmail/.com}

\section{Article Info}

Article history

Received: 27 October 2021

Accepted: 25 November 2021

Available online: 31 December 2021

Key Words: Honeybees diversity, pollination, entrepreneurship,

beekeeping scenario, $\mathrm{NEH}$ region.

\begin{abstract}
The north-eastern region of India with diverse forage resources encompasses great potential in beekeeping. The honeybee species existing in the north-eastern hill region are Apis dorsata, A. florea, A. cerana himalaya, A. mellifera, A. laboriosa and Trigona iridepennis. Modern agriculture has come to depend greatly on the bees to fulfill its pollination needs. Pollen analysis from North-eastern hill region revealed that the dominant sporomorphs were Brassica sp., Solamun sp., Helianthus sp., Wendlandia sp., Clematis sp., Adhatoda sp. and Mussaenda sp. Bee flora was identified as 107 plants from North-eastern region of India. Different types of entrepreneurship can be developed through beekeeping like honey bees rearing, sale of honey bees colonies, consultancy to farmers for honey bee rearing, processing of honey at large scale and marketing of honey products. Available information on honeybee's diversity, pollination, entrepreneurship and beekeeping scenario for sustainable agriculture of north-eastern hill region are reviewed and discussed.
\end{abstract}

Copyright (C2021 Haldhar et al., This is an open access article published under the terms of the Creative Commons Attribution License, which permits unrestricted use, distribution, and reproduction in any medium, provided the original work is properly cited.

Preferred citation: Haldhar SM, Nidhi CN, Singh KI \& Devi AS. 2021. Honeybees diversity, pollination, entrepreneurship and beekeeping scenario in NEH region of India. Journal of Agriculture and Ecology, 12: 27-43; http://doi.org/10.53911/JAE.2021.12202.

\section{Introduction}

The bees and plants are co-evolved during middle cretaceous period. The bees are depending on flowering plants as they provide food in the form of pollen and nectar. Similarly, plants are depending on the bees for pollination. The mutual interdependence of the anthrophilous insects and entomophilous angiosperms hastened their co-evolution (Suryanarayana 1986). The relationship between bees and plants stems from cretaceous times, roughly 100 million years ago. The bees (Apoidea) constitute a group of 20000 species with representatives at every level from solitary and non-social to community and true social like modern honeybees, Apis (Hargasim 1974). Integration of beekeeping with agriculture will not only benefit the farmers with the direct benefits in the form of honey, bees wax, hive products and employment opportunities, but indirectly benefit greatly through increased crop production. It has been established that almost all the agricultural crops depend upon 
pollinating insects for commercial seed/fruit production (Rao et al. 1980).

Insect pollination is extremely important as only 5.0 per cent of flowers are selfpollinated and 95.0 per cent are crosspollinated. Among 95 per cent, 85 per cent of pollination is brought about by insects. Evidently for increased crop production and sustainable agriculture, it is essential to explore the possibility of planned bee pollination. This presents an important dilemma with reduction of native pollinators on one hand and an increased need for bees for crop pollination on the other. So, modern agriculture has come to depend greatly on the bees to fulfill its pollination needs. The flowering plants of several plant families are blossoming at different time intervals of the year. Pollen and nectar availability to foraging bees fluctuated with time of the year and flowering of different species of plants. The phase of the blooming period does not commence simultaneously in all the honeyflora participating in the main honey-flow. Depending on the soil type, climatic factors and the habitat of the vegetation, the time of blooming may change for even and the same nectar plant (Rodionov \& Shaban shov 1986). The honey plants participating in the main honey-flow do not confine everywhere; each of them has restricted to quite definite climatic conditions and particular regions or area. Therefore, the types of honey harvest not similar in all the area and regions of a country. The flowering dates of some of the important honey plants in Poland has been studied and made a list of plants useful for honeybees (Gromisz 1993). Beekeeping has also become an important and sustainable source of income generation to the rural poor, landless and marginal farmers and other weaker sections of the population, particularly the tribals of north-eastern region living below the poverty line, improving their status. The major geographical regions facilitating beekeeping development are the Southern peninsular region, North east region, Indo-Gangetic plains, Northern hill region. The North eastern part, sub-Himalayan forests and cultivated areas with oilseed crops, citrus orchards were listed as one of the potential beekeeping regions (Thomas et al. 2001). Prior estimates state that the North East produces 5 lakh kg of honey annually, with 40,000 beekeepers mainly marginal with one or two hives. The wild and cultivated bee colonies contribute to the honey sourced from this region.

\section{Honeybee's diversity}

The Super family Apoidea is divided into two main subgroups: Spheciformes (Wasps), and Apiformes (Bees). Bees are distinguished from wasps by: a) the presence of branched, often plumose, hairs, and b) the hind basitarsi, which are broader than the succeeding tarsal segments. The proboscis is in general longer than that of most sphecoid wasps. Michener's (2007) report shows 17,533 species of bees worldwide, grouped under 443 genera and seven families. Of these, 633 species in 60 genera and six families were reported from India. The north-eastern states with diverse forage resources encompass great potential in apiculture. The climatic, geographical, and indigenous people practicing traditional beekeeping remarkably compliments the need for intensive development in beekeeping. The different honeybee species in the north-eastern 
hill region are the giant honeybee, $A$. laboriosa, the rock bee, A. dorsata, the little honeybee, $A$. florea, the Asian honeybee, $A$. cerana and the European honeybee, $A$. mellifera and stingless bee, Trigona iridepennis. The subspecies of Asian honeybee, A. cerana himalaya also exist in the northeastern region and its slightly differs from the A. cerana cerana of the North-west Himalayas and A. cerana indica of South India. Furthermore, the ecotypes of the subspecies, $A$. cerana himalaya with variations in their biological and economic characters among the local populations are also found in the Naga and Mizo hills, Brahmaputra valley, and Khasi hills, the foothills of the northeast Himalaya (Singh \& Verma 1992). The Hindu Kush Himalayas also inhabit the indigenous honeybees such as A. dorsata, A. florea, A. laboriosa (not domesticated) and A. cerana (domesticated). In addition to the ecosystem services such as pollination, these honeybees enhance mountain people's livelihoods through the hive products like honey and wax (Ahmad et al. 2004).

Giant honeybee, A. labriosa: These species of bees were reported long before by many researchers like Sakagami et al. (1980) in high mountainous areas of the Himalaya, which include north-eastern parts of India, Nepal, Bhutan, China (Tibet and Yannan) (Trung et al. 1996). This geographic distribution of A. laboriosa was further mapped and verified along the northeastern belt of the Arakan Mountains of eastern Arunachal Pradesh, Shillong Hills of Meghalaya, Nagaland, Manipur, and Mizoram (India) and Matupi in west-central Myanmar.
This species of honeybees is generally found at elevations between 1000-3000 MSL. A. laboriosa has a completely dark abdomen and long golden thoracic hairs but in A. dorsata has several orange or yellow anterior abdominal segments and dark thoracic hairs (Kitnya et al. 2020). The Himalayan honeybees are critical for pollination of mellitophillous plants in higher altitudes owing to the topography of the north-eastern region of India, hence also named as cliff honeybees. Although A. laboriosa exhibits seasonal migration behaviour, the nesting does not coincide with A. dorsata. Furthermore, Otis (1996) also mapped the existence of the Himalayan cliff honeybees in north-eastern India and parts of northern Myanmar. Interestingly distinct morphometric variations were observed in the morphology of drones among the two taxa collected in north-eastern India that was sympatrically existing (Kitnya et al. 2020).

Rock honeybee, A. dorsata: Apis dorsata is commonly referred to as the 'Rock bee' owing to its large body size. It is considered as key stone species in the forest ecosystem as it plays a crucial role in the sustenance of forest flora and fauna. The combs of this species measure 1.5 to $2.1 \mathrm{~m}$ from side to side and 0.6 to $1.2 \mathrm{~m}$ from top to bottom. The nests 
are not easily accessible as they are located on cliff faces located far above the ground and on the underside of branches of tall trees (Dyer \& Seeley 1994). They produce good lot of wax and honey, and are migratory in nature. Being very ferocious and inflicting painful stings these are not normally good for domestication. Existing in sympatric to Himalayan cliff bees (A. labriosa), the rock bees were found majorly in Eastern, southern and western Arunachal Pradesh (Sakagami et al. 1980; Kitnya et al. 2020). The state of Nagaland to promote the conservation of these indigenous bees, a collation on "Rock bee" is also formed by the Nagaland Beekeeping and Honey Mission (NBHM). Nevertheless, $A$. dorsata migrates long distances along river valleys into the mountains during the summer months, thus being existent throughout the northeastern stretch of India. The hives are made more on the crown branches of the Tetrameles nudiflora and trees (Kitnya et al. 2020).

Italian honeybee, A. mellifera: Apis mellifera, native to Africa, Europe and the Middle East, was introduced into India in late 70 's or early 80 's, first into Punjab, Haryana and Himachal Pradesh and later into South Indian states. Larger in size compared to $A$. cerana, it builds larger multiple combs having greater honey storage capacity than its Indian counterpart. Fecundity, brood rearing and colony build up are also much higher/ faster in this species (Atwal \& Sharma 1968; Rana \& Goyal 1994). The geographical isolation and ecological adaptation have resulted in the evolution of the races of Apis mellifera (Al-Ghamdi et al. 2013). The European bee, A. mellifera, has an average honey production of $25-40 \mathrm{~kg}$ per colony and prefers an altitude of 1500 $m$ AMSL. These exotic bees have to be migrated by floral mapping for

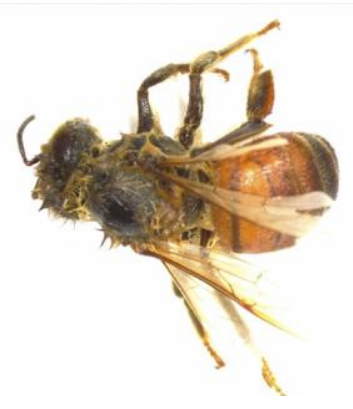
commercial beekeeping (Tej et al. 2017). As it is used for commercial beekeeping, it was successfully introduced in the Northern and Eastern plains of India (Parihar et al. 2020). Ability to acclimatize to even semi-desert tropics as well as to cold temperate zones; has made of more global in distribution. Native to western Asia, Africa, and Europe, being a good honey maker and pollinator humans introduced it into rest of Asia, Australia and America.

Indian honeybee, A. cerana himalaya: For up to two thousand years, the Asian honey bee A. cerana has been raised in indigenous cultures across the

Asian continent.

The Asian

honeybee, $\quad A$.

cerana, first

described by

Fabricius (1793)

from China, is a

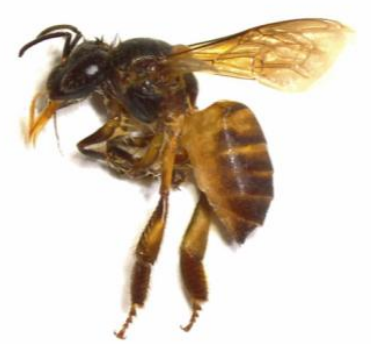

well-known bee species in India. A. c. cerana is widely distributed in China and Japan. Being the only rearable Apis bee spp. in India for commercial beekeeping before the introduction of $A$. mellifera, it was domesticated for honey and other byproducts. A. cerana has great economic potential for small- and large-scale beekeeping alike. Indeed, sustained and improved beekeeping 
with A. cerana is crucial to the species' preservation. The size is relatively smaller than rock bees and Italian bees but larger than the dwarf bees or little bees. The attributes like non-aggressiveness and closed spaceloving, parallel combs are constructed in clay pots, logs, walls, tree openings. Like other bee species, these bees also store honey in the upper part of their hive. The Langstroth bee boxes consist of the super chamber or honey chamber for honey storage and enable easy extraction (Tej et al. 2017). They yield approximately 7-9 kg of honey per colony per year. Ruttner (1988) further narrowed to a larger 'hill' variety and the smaller 'plains' variety of $A$. cerana in India. The diversity in genetic makeup and habituation of these bees further paved the way for Ruttner (1988) to classify $A$. cerana into subspecies $A . c$. cerana, A. c. indica, A. c. japonica and A. c. himalaya. A morphometric comparison was made between $A$. cerana found in the northeast Himalayan regions and the northwest and central himalayas and the size significantly.

In the North-eastern hill region, a separate subspecies of Asian honeybee, Apis cerana himalaya exists, which differed from Apis cerana cerana of North-west Himalayas and Apis cerana indica of South India. Further, there are three locally adapted populations or ecotypes of the subspecies $A$. cerana himalaya that correspond to geographic distributions in (1) the Naga and Mizo hills, (2) Brahmaputra valley and Khasi hills, and (3) the foothills of the northeast Himalayas (Singh et al. 1990; Singh \& Verma 1992). These ecotypes differ from each other in several biological and economic characters.
Due to outbreak of Thai sacbrood disease on A. cerana himalaya in the north-eastern hill region (Meghalaya, Assam and Nagaland) during 1978, exotic European honeybee, $A$. mellifera was introduced in Assam and Meghalaya for commercial beekeeping. Ruttner (1988) thus concluded that bees from the eastern Himalayas (A. cerana himalaya) differed from bees from the western Himalayas (A. cerana cerana) and South India (A. cerana indica). The subspecies $A$. cerana indica has two morphotypes: "hill bee" (black coloured) and "plain bee" (yellow coloured) (Ramchandra et al. 2012). The native northern subspecies A. c. cerana and himalaya are larger, darker coloured than A. cerana indica (Ahmad et al., 2003). The Asian honeybee is the only social high altitude dwelling species in the Asian tropics and north-eastern Asia important for pollinating agents (Said et al. 2015). The mountain farmers mainly depend on these for the source of income. The climatic conditions at an altitude of 3000 meters and the farming practices in the marginal, mountainous areas are challenging for the introduced bee species to thrive. The dynamic climatic conditions in mountain areas result in varying flowering and nectar production rhythms. Hence the native bee species of the hill regions possess ideally acclimatize to ensure the pollination of mountain crops. The bees from the backyard pollinate kitchen garden crops, usually the primary source of vegetables, mainly rapeseed mustard (Ahmad et al. 2003). 


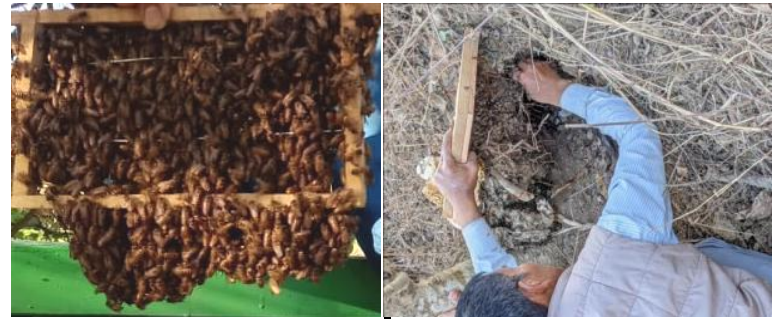

Capturing the honey bee colony of $A$. cerana cerana from forest area

Little honeybee, $\boldsymbol{A}$. florea: It is native to Southern and Southeast Asia and has a fairly widespread distribution across the low latitudes due to its preference for warm climate. These wild bee species from Asia are commonly called little or dwarf bees, owing to their small

size. It can

be found

west in the

Plateau of

Iran, Oman,

across

mainland Asia,

along the

southern border

of the Himalayas

and further east in

Vietnam,

Southeast China

and Peninsular

Malaysia

(Hepburn et al.

2005). A worker
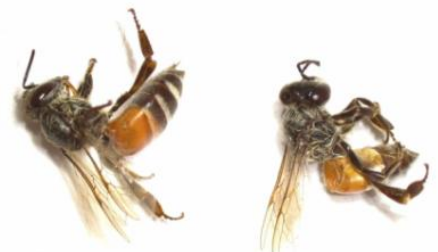

is typically $7-10 \mathrm{~mm}$ in body length and its overall coloration is red-brown. They are wild and undomesticated and yield just a few hundred grams of honey from a healthy colony (Sivram 2012). Although these bees are unproductive in honey yield, they are crucial in pollinating the wild flora, especially the small melitophillous plants like weeds and herbs that the larger bees fail to visit. When a foraging worker bee finds a resource-rich flower patch, she returns to the hive to inform the rest of the colony about the good news.
This is done through a unique and communication mechanism called the waggle dance. Information such as the direction and distance of the resource patch is encoded in the dance. Usually, the waggle dance of $A$. florea is conducted on the horizontal plane at the top of the exposed hive (Hepburn et al. 2005). Besides escaping from threatening predators, $A$. florea may also choose to abandon their nest and abscond when conditions becomes unfavorable at their current nest site, for instance loss of shade, parasitism, or lack of food. Migration from the nest can be observed upon emergence of a new queen. The older queen will move to a new site with some worker bees, leaving the young queen to inherit the old hive and establish her own colony (Oldroyd \& Wongsiri 2006).

Black dwarf honey bee, Apis andreniformis: The black dwarf honey bee, Apis andreniformis Smith 1858 , is a small dark honey bee found in Southeast Asia. It is one of two honey bee species in the subgenus Micrapis, which includes its sister, the red dwarf honey bee, Apis florea. These are thought to be the most primitive honey bee species, demonstrated by their small colonies and open-nest construction (Raffiudin \& Crozier 2007). The single comb nest of Apis andreniformis is smaller than that of Apis florea. It has a mid-rib both above and below the supporting twig of the nest, giving it a crest-like appearance (Rinderer et al. 1996). pis andreniformis is distributed throughout tropical and subtropical Southeast Asia. This bee is found as far east as the Philippines, south as Sundaland, and north as the eastern foothills of the Himalayas. Geographical distribution includes India, Southeast China, Myanmar, Laos, Thailand, Vietnam, Malaysia, and Indonesia. Apis andreniformis is the smallest and darkest honey bee species. It is approximately 6.5 to $10 \mathrm{~mm} \mathrm{(.25} \mathrm{to} .39$ inches) in length and primarily black in color. 
It is frequently misidentified as Apis florea, but can be discerned by morphological features, specifically male (drone) genitalia, and color. Apis andreniformis female worker bees have a yellow scutellum (dorsal rear portion of the thorax) in contrast to the black scutellum of Apis florea (Rattanawannee et al. 2007). The hind legs of Apis andreniformis female worker bees also have black hairs in comparison to Apis florea, which are white (Smith 1858).

\section{Dammer bee or stingless honeybee}

Member of family Apidae Trigona genus the dammer bees belong to sub- family Meliponinae, which has 7 other genera and $15 \mathrm{sub}$ genera altogether and species 500 1983). (Wille bees are most abundant in the

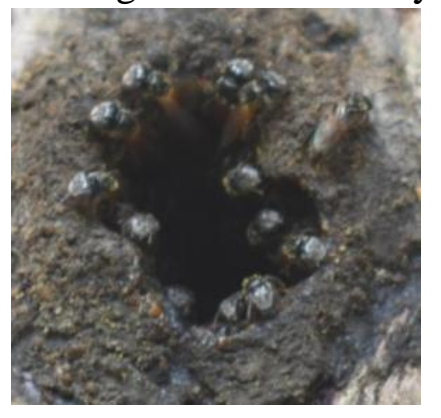
southern parts of India and along the coast in the Bay of Bengal but can also be locally common elsewhere. The interior plains of India are the least favorable areas for stingless bees. Apparently stingless bees are also to be expected in the southern parts of Pakistan, Nepal, Bhutan, and most of Bangladesh. Stingless bees of the Indian subcontinent represent the northernmost distributed stingless bees, globally, although the precise distribution in the region is only fragmentarily known. Inhabiting such northern latitudes for a social insect with limited adaption to cold conditions for extended periods, even below freezing for multiple days, should motivate new behavioral and physiological studies to be conducted in the northern parts of India. Dammer is a kind of resin for construction of their nest along with wax produced from their body. These smallest of bees are stingless although they bite the intruders in defense. The bees' number in a colony might range from a hundred to thousands or more (Michener 2000). Trigona comb differs from those of other honeybees of Apis genus in having elliptical cells instead of hexagonal ones. Resin than wax is major substance used for comb making unlike in other honeybees. It is easier to domesticate Trigona but honey production is much lesser. The honey, dark and bitter, is attributed with medicinal importance and highly valued. The nests are built in trunks of trees, logs, wall crevices or under the roofs of dwellings. In the nest, there is a group of separate cells for brood rearing and another group of larger "sacs" for storage of pollen and honey.

\section{Pollen and nectar yielding plants in NEH region}

The north-eastern hill region has great potential for the development of beekeeping because of its richness in forests, agricultural and horticultural crops. Unfortunately this industry has not tremendous progress so far, possibly due to lack of knowledge on modern bee management technology and the honey plant resources. Pollen analysis of honey samples collected from north-eastern hill region revealed that the dominant sporomorphs were of Brassica sp., Solanum sp., Helianthus, Wendlandia sp., Ageratum sp., Clematis sp., Adhatoda sp., Mu ssaenda sp. and Papilionaceous, Rubiaceous, Rutaceous and Zingiberaceous members. The minor pollen sources were Litsea sp., Ocimum sp., Caesalpinia sp., Parkia sp., Bauhina sp., Senecio sp., Polygonum sp., and members of families Asteraceae, Bignonaceae, Euphorbiaceae, Lamiaceae, Lauraceae, Malvaceae, Myrtaceae, Papilionaceae, Polygonaceae, Ranunculaceae, Rosaceae, Rubiaceae, Rutaceae, Scrophulariaceae and Zingiberaceae (Singh et al. 1994; Singh 1999). 
Table 1. Monthly calendar for honeybees pollen and nectar yielding plants for Manipur region

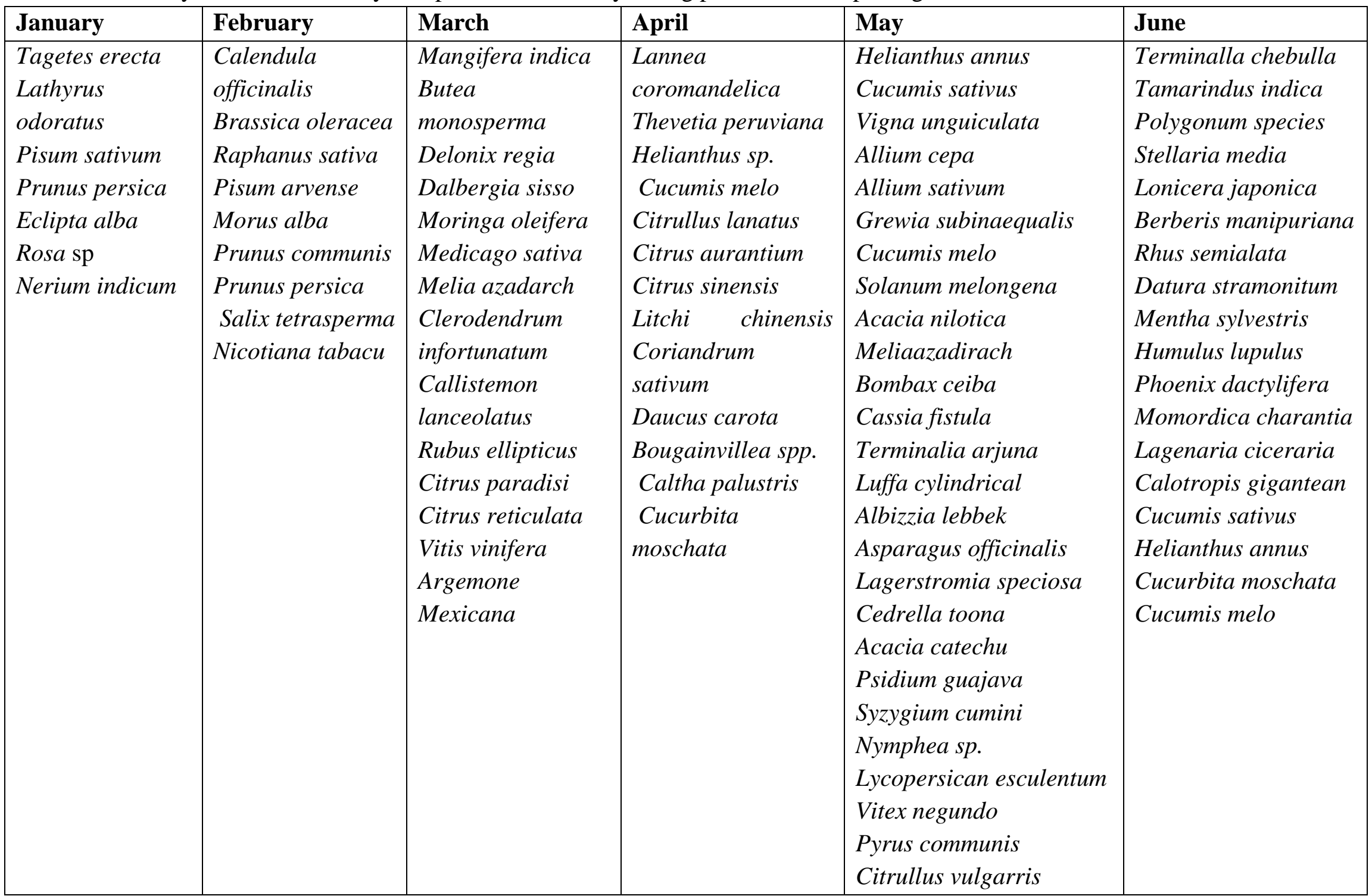




\begin{tabular}{|c|c|c|c|c|c|}
\hline & & & & $\begin{array}{l}\text { Capsicum frutescens } \\
\text { Rubus nivens } \\
\text { Ranunculus scleratus } \\
\text { Punica granatum } \\
\text { Portulaca grandiflora } \\
\text { Artemissia nilagirica }\end{array}$ & \\
\hline July & August & September & October & November & December \\
\hline $\begin{array}{l}\text { Sonchus } \\
\text { oleraceus } \\
\text { Carica papaya } \\
\text { Ipomaea palmate } \\
\text { Phyllanthus } \\
\text { emblica } \\
\text { Zea mays } \\
\text { Sesamum } \\
\text { indicum } \\
\text { Cannavis sativa } \\
\text { Nelumbium } \\
\text { speciosum } \\
\text { Zinnia elegans } \\
\text { Acacia nilotica } \\
\text { Cucumis sativus } \\
\text { Helianthus annus } \\
\text { Cucurbita } \\
\text { moschata }\end{array}$ & $\begin{array}{l}\text { Celosia argentia } \\
\text { Commelina } \\
\text { bengalensis } \\
\text { Ricinus communis } \\
\text { Magnolia } \\
\text { glandiflora } \\
\text { Gossypium } \\
\text { hirsutum } \\
\text { Gossypium } \\
\text { arboretum } \\
\text { Fagopyrum } \\
\text { esculentum } \\
\text { Dolichos lablab } \\
\text { Cajanus cajan } \\
\text { Acacia nilotica } \\
\text { Cucumis sativus }\end{array}$ & $\begin{array}{l}\text { Crotolaria juncea } \\
\text { Musa paradisiaca } \\
\text { Zizyphus } \\
\text { mauritiana } \\
\text { Gossypium } \\
\text { arboretum } \\
\text { Musa paradisiaca } \\
\text { Cajanus cajan } \\
\text { Asparagus } \\
\text { officinalis } \\
\text { Vigna unguiculata } \\
\text { Cucumis sativus } \\
\text { Helianthus annus }\end{array}$ & $\begin{array}{l}\text { Brassica campestris } \\
\text { var toria } \\
\text { Citrus aurantifolia } \\
\text { Musa paradisiaca } \\
\text { Crotolaria juncea } \\
\text { Cajanus cajan } \\
\text { Dolichos lablab } \\
\text { Fagopyrum } \\
\text { esculentum } \\
\text { Asparagus } \\
\text { officinalis } \\
\text { Luffa cylindrical }\end{array}$ & $\begin{array}{l}\text { Glycine max } \\
\text { Eucalyptus spp. } \\
\text { Dahlia variabilis } \\
\text { Brassica campestris var } \\
\text { toria } \\
\text { Citrus aurantifolia } \\
\text { Cajanus cajan } \\
\text { Solanum melongena }\end{array}$ & $\begin{array}{l}\text { Euphorbia } \\
\text { pulcherrima } \\
\text { Phlogacanthus } \\
\text { thyrisiformis } \\
\text { Justicia adhatoda } \\
\text { Brassica juncea } \\
\text { Fragaria x ananassa } \\
\text { Coriandrum sativum } \\
\text { Foeniculum vulgare } \\
\text { Vicia sativa } \\
\text { Lindernia ciliata } \\
\text { Verbena officinalis } \\
\text { Chrysanthemum spp }\end{array}$ \\
\hline
\end{tabular}




\section{Role of honeybees in crop pollination}

At present, several countries of the Hindu Kush-Himalaya are making desperate efforts to achieve self-sufficiency in food production, by physical expansion of the area under cultivation and better management of resources. These include use of better quality seeds and animals, bringing more wasteland under cultivation, the use of fertilizers, pesticides, and bringing in more irrigation. However, in the past decade or so, food production has come to a point of stagnation for some cultivated crops. Emphasis in the future should be on the full utilization of under-utilized resources/services such as enhanced pollination services by honeybees to increase productivity of various cultivated crops. The vital role which honeybees play in the pollination of large numbers of agricultural and horticultural crops is often underestimated. As a matter of fact, the main importance of honeybees and beekeeping is pollination, whereas, hive products, such as honey and beeswax, are of secondary value (Verma 1992; Thapa 2006). This is evident by the fact that income from agriculture by the use of honeybees for crop pollination is many times greater than their value as honey and beeswax producers (Verma \& Dulta 1987). Many cultivated crops do not yield seeds or fruits without cross pollination of their flowers by honeybees and other wild insects. Crosspollination of entomophilous crops by honeybee is one of the most effective and cheap methods of increasing their yield. Other agronomic practices, such as the use of manure, fertilizers, pesticides and irrigation are cost-effective, but these may not yield the desired results without the use of honeybees to enhance the productivity levels of different cultivated crops through pollination. It is not only the self-sterile varieties or cultivars which require crosspollination, but also the self-fertile forms which also produce more and better quality seeds and fruits if pollinated by honeybees and them (Verma \& Dulta 1987). Only a few attempts have been made in the north-eastern hill region to identify important insect pollinators and to assess the pollination requirements of agricultural and horticultural crops.

Rapeseed and mustard: Surveys conducted at twenty oilseed growing localities belonging to six districts of Manipur showed that the Asian honeybee, Apis cerana himalaya and flower fly, Episyrphus balteatus were the main pollinators of rapeseed and mustard, which constituted 72 and 26 per cent, respectively of the total pollinators population. Other visitors were rock bee, Apis dorsata, bumble bee, Bombus tunicatus, cabbage butterfly, Pieris brassicae, housefly, Musca sp. and alkali bee, Nomia curvipes, however, they do not visit the crop in sufficient numbers (Singh et al. 1993). A.c. himalaya was observed to start its foraging activity at 0800 hours and ceased at 1600 hours. The peak population of foraging bees was observed between 0900 and 1100 hours. The bees spent an average of 6.4 seconds per flower with foraging rate of 10 flowers per minute. During the hours of the day, the number of nectar collector's increased from morning to evening, whereas the trend was reverse for pollen collectors. The average duration of single foraging trip was 8.6 minutes with maximum pollen load of 9.6 $\mathrm{mg} / \mathrm{bee}$ at 1200 hours (Singh et al. 1998b). 
Similarly, Mahanta and Rahman (1997a) found $437.5 \%$ higher yield of rapeseed in Assam in bee pollinated as compared to selfpollinated crop. Further, Singh and Devi (1997) reported that in rapeseed at least five bee visits per flower are required for good pollination. The crop pollinated by bees enhanced siliqua setting, length of siliqua, number of seeds per siliqua and seed weight. Interestingly, the oil content in seeds of bee pollinated plants increased to the extent of $21.3 \%$ and $4.1 \%$ as compared to selfpollinated and pollinated by natural insects, respectively. Germination of seeds from bee pollinated plants was also $50.9 \%$ higher than from self-pollinated and $2.5 \%$ higher than from pollinated by natural insects (Singh et al. 1998a).

Sunflower: Under the agro-climatic conditions of Manipur, the Asian honeybee, Apis cerana himalaya and rock bee, Apis dorsata were the predominant pollinators of sunflower, which constituted 46 and 42 per cent, respectively of the total pollinators population. Other insect visitors were little bee, Apis florea, bumble bees, Bombus haemorrhoidalis and $B$. tunicatus, carpenter bee, Xylocopa aestuans, alkali bee, Nomia curvipes, leaf cutter bee, Megachile umbripennis, sweet bee, Halictus albescens, drone flies, Ischiodon scutellaris and Episyrphus

balteatus and cabbage butterfly, Pieris brassicae, however, they do not visit the crop in sufficient numbers. A.c himalaya was observed to start its foraging activity at 0519 hours and ceased at 0608 hours during winter. Bees foraged throughout the day, but the peak foraging activity was observed between 0600 and 0900 hours and spent an average of 53 seconds per flower head with foraging rate of 2 flower heads per minute. During the hours of the day, the number of nectar collectors increased from morning to evening, whereas, a reverse trend was observed for pollen collectors. The average duration of foraging trip of bees was 3.4 minutes with maximum pollen load of $5.8 \mathrm{mg} / \mathrm{bee}$ at 1400 hours (Singh et al. 1998b). The sunflower crop pollinated by bees enhanced $801 \%$ and $12 \%$ higher seed yield than self-pollinated and pollinated by natural insects, respectively. The seed setting in bee-pollinated plants was also observed $2343 \%$ and $18.3 \%$ higher than selfpollinated and pollinated by natural insects, respectively. The oil content in seeds and seed germination rate could also be increased in the seeds pollinated by bees (Singh et al. 1998a).

Niger: Among the bee species, Apis cerana, A. dorsata, A. florea, A. mellifera and Chalicodoma lanata were found pollinating niger crop in Assam. Peak foraging activity of $A$. cerana was observed between 1000 and 1200 hours. The time required collecting pollen ranged from 4.89 to 7.23 seconds per capitulum and the number of foragers visiting flowers was directly related to the temperature and sunshine intensity. There was 120.2 per cent increase of seed yield in bee pollinated plots and five $A$. cerana colonies per ha were recommended (Rahman 1993).

Citrus: Bhuyan and Bhattacharyya (2002) studies the foraging activity of honeybee on Assam lemon and concluded that the duration of their visits was more in the morning hours in comparison to mid day, while individual honeybee visited more frequently in the 
morning and decreased subsequently towards evening. Citrus species and varieties greatly vary in their pollination needs. Sweetlime and mandarin oranges are generally benefited from cross pollination. Bhuyan and Bhattacharya (2002) study the effect of honeybee on Assam lemon and found 77 per cent fruit set in honeybee pollinated trees as compared to 46 per cent in naturally pollinated ones. They recorded $52.2 \%$ yield increase in Assam lemon due to bee pollination and recommended four $A$. cerana colonies per ha for optimum yield. A study conducted by Gogoi et al. (2007) on Assam lemon pollinated by $A$. cerana also revealed that the crop pollinated by bees gave $52.17 \%$ fruit set as compared to $40.80 \%$ in open pollinated and $27.35 \%$ in self pollinated plants. Due to A.cerana pollination, 214.79 per cent increased yields was recorded over selfpollinated treatment. The average fruit length, girth, weight and juice content in $A$. cerana pollinated plants were $12.93 \mathrm{~cm}, 17.40$ $\mathrm{cm}, 199.46 \mathrm{gm}$ and $655.99 \mathrm{cc}$, respectively, which were significantly higher than fruits of open pollinated and self-pollinated plants.

Litchi: Litchi is a popular fruit plant in sub Himalayan region as known for its expensive fruit. It blooms in February-March and is rich source of nectar to bees. Wind pollination does occur but fruit set is higher by insect pollination and little or no fruit set is obtained under selfing. Honeybees and stingless bees comprise more than $90 \%$ of the flower visitors. The study made by Mahanta and Rahman (1997b) on litchi found that $A$. cerana visit was maximum during 0900 to1100 hours of the day. The average number of bees was highest during 1000 to 1100 hours and frequency of flower visit was highest during 1500 to 1600 hours of the day. Five colonies of $A$. cerana per ha gave optimum yield of litchi with $123.97 \%$ increase in yield against self-pollination.

Cucumber: Islam (2007) studied the foraging behavior of $A$. cerana on cucumber and its role on fruit set and yield in Assam. Pollinators visiting the cucumber flower consisted of Asian honeybee, Apis cerana, European honeybee, Apis mellifera, rock bee, Apis dorsata, carpenter bees, Xylocopa leucothorax and $X$. fenestrata, wasps, Polystis habrious and Vespa magnifica, peacock pancy, Junonia almanaa, lemon butterfly, Papilio demoleus, grey count, Euthalia lepidae, housefly, Papilio demoleus, grey count, Euthalia lepidae, housefly, Musca domestica and ant, Oecophylla smaragdinae. Among theses, $A$. cerana was found to be the predominant pollinator which constituted $51.4 \%$ of the total pollinators population. The peak foraging activity of $A$. cerana was observed during 0800 to 0900 hours of the day. The cucumber crop pollinated by $A$. cerana enhanced $25.21 \%$ and $48.6 \%$ higher fruit yield than self-pollinated and pollinated by natural insects, respectively and recommended seven $A$. cerana colonies per ha for optimum yield. Similarly, maximum fruit set $(19.2 \%)$ was also observed in bee pollinated plants against self-pollinated $(5.5 \%)$ and pollinated by natural insects $(12.8 \%)$.

\section{Entrepreneurship through honeybees}

- Honey bees rearing

- Sale of honey bees colonies

- Consultancy to farmers for honey bee rearing 
- Processing of honey at large scale

- Marketing of honey products

\section{Beekeeping scenario in NEH region}

North East India is rich in biodiversity of unique floral resources, honeybee species and congenial climatic conditions for beekeeping. Still, the potentiality of becoming one of the 'honey capital' is yet to be explored. The reasons may be lack of awareness, lack of integration of beekeeping with agriculture, scarcity of skilled workforce and commercialization. Despite their importance in pollination, the population size of native bees is diminishing in the region. The habitat loss through land-use changes, inclination towards monoculture and indiscriminative use of pesticides and herbicides significantly threaten the survival of the indigenous bees (Ahmad et al. 2003). As per the report of ICIMOD, the population density of $A$. cerana himalaya in the region is declining because of many reasons, i.e., extensive inclusion and promotion of $A$. mellifera species by the public and private sector through developmental intrusion, alteration in their habitat and biodiversity, non-judicious use of pesticides, diseases and parasites attack, etc. (Said et al. 2015). The adoption of organic farming as recently Sikkim, in northeast India, was declared the first organic state in India is thoughtful in diminishing pesticide use.(Bansal et al. 2013; Sharma et al. 2014) The Thai sacbrood disease devastated A. cerana himalaya in the north-eastern hill region during 1978. This led to the introduction of an exotic European honeybee, A. mellifera, for commercial beekeeping.
As the productivity of $A$. mellifera is comparatively higher than the Asian bees, it has been adopted for commercial beekeeping in significant parts of the country. Unfortunately, introduction to the hill regions of the northeast has threatened the livelihoods of mountain farmers. The challenges for indigenous bee species include competition for nectar in these areas and susceptibility to diseases and harmful mites. In addition to these extensionists encouraging the introduction of $A$. mellifera in these areas of origin of A. cerana himalaya, a constant threat to the indigenous beekeepers. However, $A$. mellifera is less adaptive to the local climatic conditions and the indigenous vegetation, making it a less effective pollinator (Ahmad et al. 2003). Conservation of indigenous species is a vital step in natural resource management. The wild bees, A. dorsata and A. laboriosa, $A$. florea, must be conserved. In contrast, the Asian hive bee, A. cerana himalaya, must be promoted through selection and breeding in collaboration with local communities. Promoting native Asian honey bees and using breeding techniques similar to those for $A$. mellifera should maximize the ecological and economic benefits of this well-adapted and genetically valuable species. However, current breeding efforts with $A$. cerana himalaya have been limited and instrumental insemination is difficult. A. cerana himalaya bee species still prove to be a potential pollinator in conserving the biodiversity of the north-eastern region through its ecosystem services. 


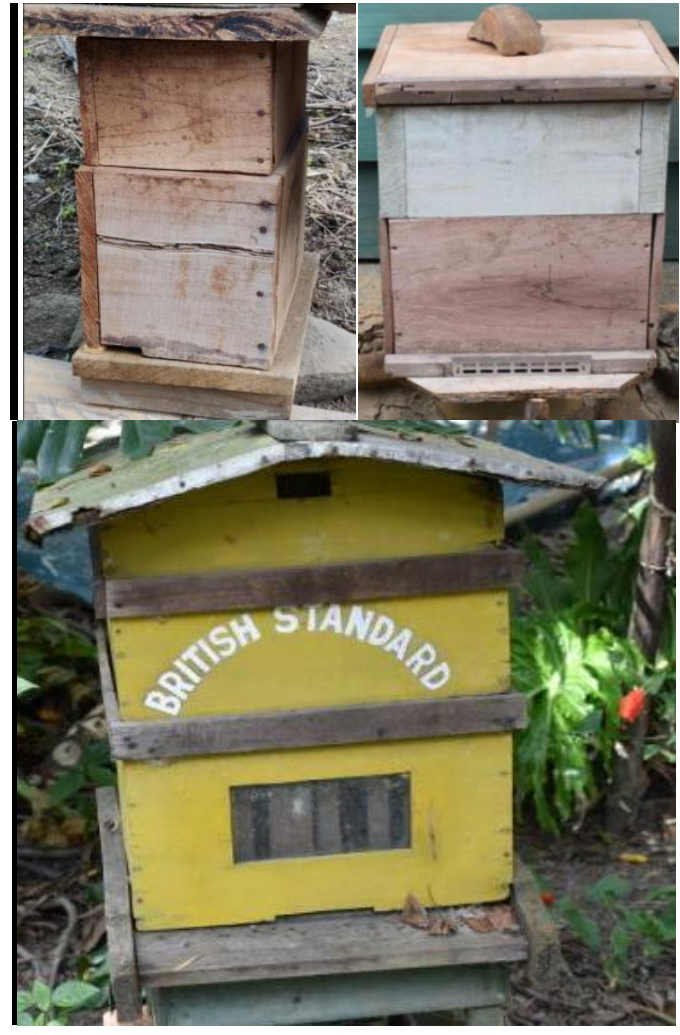

Locally made bee hives of $A$. cerana himalaya

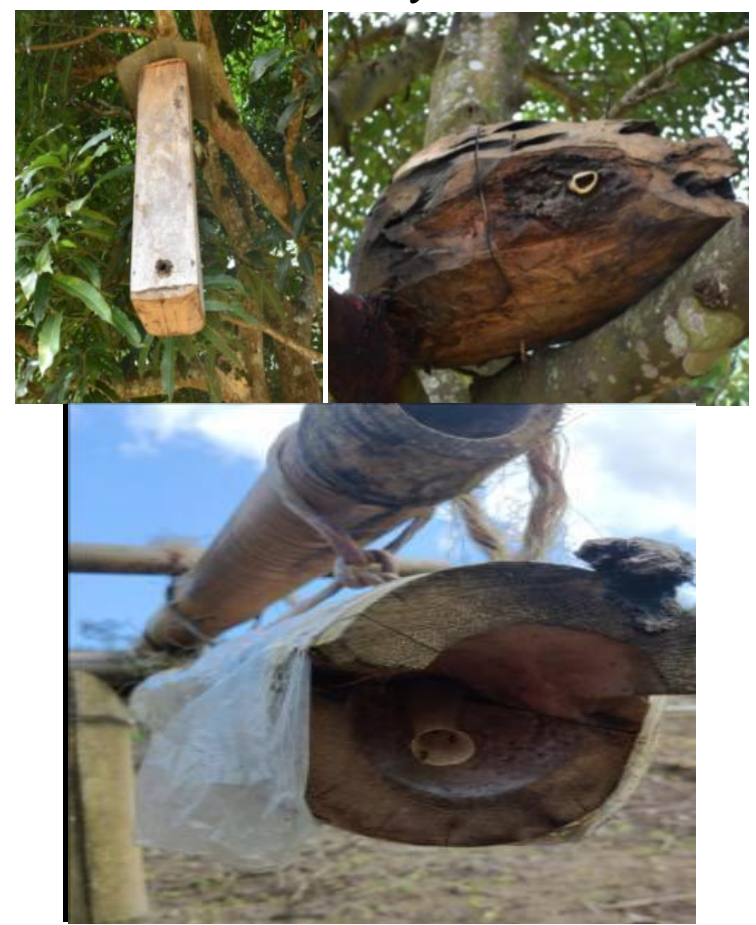

Locally made bee hives of stingless bees
The north-eastern region's tribals are primarily more proficient in sourcing feral colonies of domesticated species of bees, especially A. cerana cerana and A. cerana himalaya, for honey production. However, the traditional practices of beekeeping by the tribes living in the northeast belt do not contribute to the conservation of honeybees. They are not backed up by a scientific approach, thus making them baseless. The practices of collecting the honey of the wild bees by destruction method are factors for diminishing bee populations. Immediate conservation efforts are required for the pollinator-agriculture phase involving location-specific researches. Suitable training and awareness programs about the importance of the feral colonies and their pollination services need to be carried out to better the beekeeping scenario in the northeastern regions.

\section{References}

Ahmad F, Joshi SR \& Gurung MB. 2003. The Himalayan cliff bee Apis laboriosa and the honey hunters of Kaski. Indigenous honeybees of the Himalayas (Volume I). ICIMOD, Kathmandu. 52.

Al-Ghamdi AA, Nuru A, Khanbash MS \& Smith DR. 2013. Geographical distribution and population variation of Apis mellifera jemenitica Ruttner. Journal of Apicultural Research, 52(3): 124-133.

Atwal AS \& Sharma OP. 1968. The introduction of Apis mellifera queens into Apis indica colonies and the associated behavior of the two species. Indian Bee Journal, 30: 41-56. 
Bansal K, Singh Y \& Singh P. 2013. Constraints of apiculture in India. Int $J$ Life Sci Res, 1(1):1-4.

Bhuyan M \& Bhattacharyya PR. 2002. Foraging of honeybee upon Assam lemon (Citrus acida Roxb.) under agroclimatic condition of Jorhat, Assam, India. Geobios, 29: 33-36.

Dyer EC \& Seeley TD. 1994. Colony migration in the tropical honey bee Apis dorsata F. (Hymenoptera, Apidae). Insect. Soc., 41: 129- 140.

Gogoi B, Rahman A, Rahman S \& Deka MK. 2007. Foraging behavior and effect of Apis cerana pollination on fruit set and yield of Assam lemon (Citrus lemon L. Burn). Indian Journal of Agricultural Sciences, 77 (2): 120-122.

Gromisz M. 1993. Flowering dates of some important honey plants in Poland in the years 1946 - 1986. Pszczelnicze Zeszyty Naukowe, 37: 89-101.

Hargasim O. 1974. Bees as pollinators of entomophilous crops. Bee World, 55 (4): 137-140.

Hepburn RH, Radloff S, Otis G, Fuchs S, Verma L, Tan K, et al. 2005. Apis florea: morphometrics, classification and biogeography. Apidologie, 36 (3): 359376.

Islam N. 2007. Role of Apis cerana (Hymenoptera, Apidae) on fruit set and yield of cucumber, M.Sc. thesis, Assam Agricultural University, Jorhat, pp. 47.

Kitnya N, Prabhudev MV, Bhatta CP, Pham TH, Nidup T, Megu K, Chakravorty J, Brockmann A. \& Otis GW. 2020. Geographical distribution of the giant honey bee Apis laboriosa Smith, 1871 (Hymenoptera, Apidae). ZooKeys, 951, p.67.

Mahanta M \& Rahman A. 1997a. Pollination studies on honeybees (Apis cerana indica) on rapeseed, Brassica campestris var. toria. Plant Health, 2: 66-69.

Mahanta M \& Rahman A. 1997b. Studies on pollination of litchi (Litchi chinensis Sonn) by honeybee (Apis cerana F.). Indian Bee Journal, 59 (2):74-75.

Michener CD. 2007. The Bees of the World. Second ed., The Johns Hopkins University Press, Baltimore and London, USA and UK.

Michener CD. 2000. The Bees of the World, Johns Hopkins University Press. Baltimore.

Oldroyd B \& Wongsiri S. 2006. Asian honey bees. Cambridge, Mass.: Harvard University Press.

Otis GW. 1996. Distributions of recently recognized species of honey bees (Hymenoptera: Apidae; Apis) in Asia. Journal of Kansas Entomological Society, 69: 311-333.

Parihar A, Thakur M, Rana K \& Devi S. 2020. Quality analysis of Apis cerana and Apis mellifera honey from Himachal Pradesh, India. Journal of Entomology and Zoology Studies, 8: 46-54.

Raffiudin R \& Crozier RH. 2007. Phylogenetic analysis of honey bee behavioral evolution. Molecular Phylogenetics and Evolution, 43: 543552. 
Rahman A. 1993. Role of honeybee, Apis cerana indica $\mathrm{F}$. in pollination and seed set of niger. In : Pollination in Tropics (Eds. G.K. Veeresh, R. Uma Shankar and K.N. Ganeshaiah). IUSSI Indian Chapter, Bangalore, pp. 212 214.

Ramchandra TV, Subashchandran MD, Joshi NV \& Balachandran C. 2012. ENVIS technical. report: 49, Centre for ecological sciences. Indian Institute of Science, Bangalore.

Rana BS \& Goyal NP. 1994. Comparative brood rearing activity of Apis mellifera and Apis cerana indica at Nauni (Solan), midhills of Himachal Pradesh. Indian Bee Journal, 56: 24-28.

Rao G. Mohan, Suryanarayana MC \& Thakur CV. 1980 Bees can boost oilseed production. Indian Farming. 29: 25-26.

Rattanawannee A, Chanchao C \& Wongsiri S. 2007. Morphometric and genetic variation of small dwarf honeybees Apis andreniformis Smith, 1858 in Thailand. Insect Science, 4: 451-460.

Rinderer TE, Wongsiri S, Kuang B, Liu J, Oldroyd BP, Sylvester HA \& de Guzman LI. 1996. Comparative nest architecture of the dwarf honey bees. Journal of Apicultural Research, 35: 1926.

Rodinov VV \& Shabanshov. 1986. The Fascinating world of bees. Mir Publishers, Moscow (Russia).

Ruttner F. 1988. Biogeography and taxonomy of honeybees. Springer, Berlin.

Said F, Inayatullah M, Ahmad S, Iqbal T \& Shah RA. 2015. Foraging behavior of the Himalayan Honeybee, Apis cerana
(Hymenoptera: Apidae) associated with sunflower (Helianthus annuus L.) at Peshawar District of Khyber Pakhtunkhwa (KP). Journal of Entomology and Zoology Studies, 3 (3): 203-207.

Sakagami SF, Matsumura T \& Ito K. 1980. Apis laboriosa in Himalaya, the little known world largest honeybee (Hymenoptera: Apidae). Insecta Matsumurana, 19: 47-77.

Sharma SK, Kumar Y \& Rana MK. 2014. Status and prospects of beekeeping in Haryana. Workshop on promotion of honeybee keeping in Haryana held on June 242014.

Singh MP. 1999. Melissopalynology and survey of the bee plants in North-eastern hill region. Indian Journal of Hill Farming, 12 (1 \& 2): 79-83.

Singh MP \& Devi CS. 1997. Effect of repeated flower visitation by Apis cerana Fab. on pod and seed setting in rapeseed. Insect Environment, 3 (2): 40.

Singh MP \& Verma LR. 1993. Morphometric comparison of three geographic populations of the northeast Himalayan Apis cerana.Asian Apiculture (LJ Connor, T. Rinderer, HA Sylvester \& S. Wongsiri eds) Wicwas Press USA, pp.67-73.

Singh MP, Singh KI \& Devi CS. 1998a. Role of Apis cerana himalaya pollination on yield and quality of rapeseed and sunflower crops. In:Asian Bees and Beekeeping: Progress of Research and Development (Eds. M. Matsuka, L.R. Verma, S. Wongsiri, K.K. Shrestha and 
U. Pratap) Oxford and IBH Publishing Company, New Delhi, pp. 186 - 189.

Singh MP, Singh KI \& Devi CS. 1998b.

Foraging behavior of Apis cerana himalaya on sunflower and rapeseed. In:Asian Bees and

Beekeeping: Progress of Research and Development (Eds. M. Matsuka, L.R. Verma, S. Wongsiri, K.K. Shrestha and U. Pratap) Oxford and IBH Publishing Company, New Delhi, pp. 199- 202.

Singh MP, Verma LR \& Daly HV. 1990. Morphometric analysis of the Indian honeybee in the North-east Himalayan region. Journal of Apicultural Research, 29 (1):3-14.

Singh MP, Verma LR \& Mattu, VK. 1994.

Pollen spectrum of some honeys of the North-east Himalayas as determinant of honeybee forage. Indian Bee Journal, 56 (1-2):37-52.

Smith F. 1858. Catalogue of the hymenopterous insects collected at Sarawak, Borneo; Mount Ophir, Malacca; and at Singapore, by A R Wallace. Proceedings of the Linnaean Society of London, 2: 42-130.
Suryanarayan MC. 1986. Honeybee - flower relationship. Bulletin of Botanical Survey of India, 28(1-4): 55 - 62.

Tej MK, Aruna R, Mishra G \& Srinivasan MR. 2017. Beekeeping in India. In Industrial Entomology (pp. 35-66). Springer, Singapore.

Thapa RB. 2006. Honeybees and other insect pollinators of cultivated plants: a review. Journal of Institute of Agriculture and Animal Sciences, 27:1-23.

Thomas et al, Proc. 37th Int. Apic. Congr., 28 Oct - 1 Nov 2001, Durban, South Africa.

Trung LQ, Dung PX \& Ngan TX. 1996. A scientific note on first report of Apis laboriosa F Smith, 1871 in Vietnam. Apidologie, 27: 487-488.

Verma LR. 1992. Honeybees in Mountain Agriculture. International Centre for Integrated Mountain Development; Kathmandu, Nepal. 69 p.

Verma LR \& Dulta PC. 1987. Role of insect pollinators on yield and quality of apple fruit. Indian Journal of Horticulture, 44:274-279.

Wille A. 1983. Biology of stingless bees. Annual Review of Entomology, 28: 4164. 